\title{
Life Cycle Perspectives on Human Health Impacts of I onic Liquids
}

\author{
Amirhossein Mehrkesh and Arunprakash T. Karunanithi \\ Centerfor Sustainable Infrastructure Systems, University of Colorado Denver, Denver, Colorado, 80217
}

\begin{abstract}
This study aims to develop a correlative approach to predict the non-cancer human health impacts associated with the direct environmental exposure of common ionic liquids. We assessed the human health impact of these ionic liquids through the integration of the USEtox model with toxicity data and fate and transport parameters. For the first time, we report non-cancer human health characterization factors for commonly us ed ionic liquids. On the one hand, literature related to environmental aspects of ionic liquids either promotes their environmentally friendly "green" aspects due to their negligible volatility (no air emissions). On the other hand, a great deal of literature promotes their "non-green" aspects due to the high toxicity values of certain ionic liquids towards living organisms. In this study, we attempt to integrate these two different diverging opinions to look at the concept of the "greenness" of ionic liquids from a larger point of view (i.e. from a life cycle assessment perspective).
\end{abstract}

Keywords: Ionic Liquids, Toxicity, Human Health, USEtox

\section{Introduction}

In recent years, the focus on finding new applicationsfor lonic liquids (ILS) has increased significantly. lonic Liquids are, a relatively new class of chemicals, show unique properties such as negligible volatility, nonflammability, high thermal stability, and wide electrochemical windows. These unique and promising characteristics make ionic liquids good candidates for a variety of applications including chemical synthesis ${ }^{1}$, solventextraction, ${ }^{2,3}$ electrochemistry ${ }^{4}$, carbon capture ${ }^{5}$, cellulose processing ${ }^{6}$, thermal energy storage $^{7,8}$, biomechanics ${ }^{9}$, microfluidics ${ }^{10}$, and many more.

Published literature on ionic liquids has grown exponentially since 1999. New applications are being found for ionic liquids, which has helped these newer compounds find their way into the industrial applications. ${ }^{11}$ Ionic liquids are often considered as being inherently green solvents, which have the potential to replace the traditional organic solvents in several applications, mostly due to their non-volatile nature. This advantageous property limits their direct impact on air quality by reducing their emissions to the atmosphere. However, during the past few years, several research studies have countered the view of ionic liquids being all green, and instead reported that many ionic liquids unfortunately shown high toxicity values toward living organisms such as mammals and human cell lines (e.g. HeLa cells). ${ }^{12}$ Even though we believe that both contradictory arguments have their own merits, a realistic picture can certainly be drawn up through the analysis of the human health impacts associated with the life cycle of ionic liquids (from the production of precursor materials to the point of release of ILs into the environment).

Ionic liquids are not yet produced on a large commercial scale, but since the field is developing very rapidly, it is essential to consider their environmental impacts (such as human health impacts) at the design stage rather than after their production. 
Research has been focused on toxicity of ionicliquids and their impacts on human health and ecology. ${ }^{13-}$ ${ }^{15}$ Several research have studied the toxicity of ionic liquids towards different living organisms including bacteria such as E.coli, ${ }^{16,17}$ and Vibrio fischeri ${ }^{18}$, microalga such Pseudokirchneriella subcapitata (PKS), planktons such as Daphnia magna and fish such as Danio rerio (zabra fish). ${ }^{19}$ However, there is still a long way to have a universal knowledge on the potential hazard, bioaccumulation, biodegradability and ecotoxicity of ionic liquids as well as their impact on the human health. ${ }^{13-15,20-21}$ To date, the effect of room temperature ionic liquids (RTILs) on some microorganisms and human cell lines has been studied. Ganske et al. showed in their paper that RTILs can potentially have significant inhibitory effects on the growth of microorganisms such as E.coli, Pichia pastoris and Bacilluscereus. ${ }^{16}$ Among the published literature on the topic of toxicity of ionic liquids (ILS), only few a have studied the toxicity of RTILs on human cell lines, such as prototypical human epithelial Caco-2, HeLa cells (an immortal human cell line), and human colon carcinoma HT-29 cell lines. ${ }^{22,23}$ Since potentially a wide variety of ionic liquids consisting of different cations, anion and side chain groups can be synthetized, it is important to develop correlative or QSAR models to predict the toxicity of ionic liquids towards different organisms. This study aims to develop a correlative model to predict the non-cancer human health toxicity of ionic liquids, ED50, from their invitro cytotoxicity data.

\section{Methods}

Two correlative approaches were used to convert the in-vitro (toxicity towards microorganisms) cytotoxicity data $\left(\mathrm{IC}_{50}\right)$ to in-vivo toxicity (toxicity towards mammalian species such as rat and mouse) data $\left(\mathrm{LD}_{50}\right)$ and in the next step another correlation was used to predict in-vivo toxicity data to non-cancer human heath toxicity.

An EPA document reported a correlation model (Multicentre Evaluation of In-Vitro Cytotoxicity) along with a methodology developed for a select number of chemical compounds to predict the in-vivo toxicity values $\left(\mathrm{LD}_{50}\right)$ from in-vitro cytotoxicity data. ${ }^{24}$ In this study, we improved this general correlation by using more categorized chemicals resulting in having a better the correlation coefficient, $R^{2}$, as shown in Fig.1.

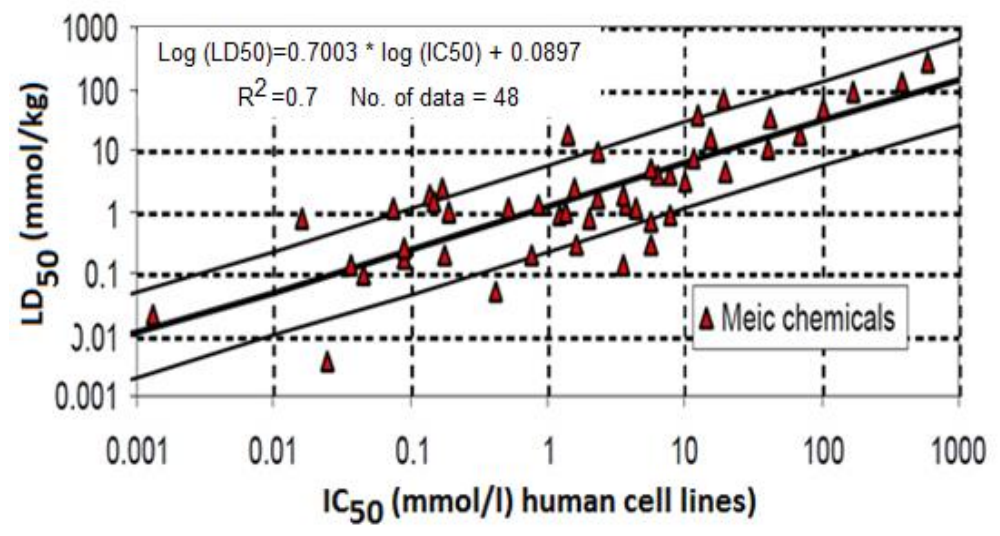

Fig.1 A correlative linear model of $\mathrm{LD}_{50}$ toxicity data 
$\mathrm{LD}_{50}$ or the lethal dose of $50 \%$, is the amount of a chemical which kills $50 \%$ of the population of a test species (used in toxicity evaluations) exposed to that. The EPA study used I $C_{50}$ toxicity data of selected chemicals towards HeLa cell lines to predict their in-vivo $\left(L_{50}\right)$ toxicity values. $I C_{50}$ is an index of the toxicity of a substance defined as the concentration of that chemical which have inhibitory effects on the growth of the $50 \%$ of the test population. HeLa cell used in this study is an immortal cell line, which is the oldest yet most commonly used human cell line for scientific research. ${ }^{25}$ In the next step, we explain how $\mathrm{LD}_{50}$ data predicted from the EPA's correlative model can be further used to estimate the human health impacts of ionicliquids.

\subsection{Life Cycle Assessment (LCA)}

As it was mentioned earlier, to have a realistic perception on the greenness of a chemical compound, a life cycle assessment is needed as a comprehensive and reliable approach towards the quantification of the compound's greenness.

LCA is a method or technique used to assess the environmental impacts associated with the life cycle of a product, process, or service through, compiling a general inventory including relevant energy/material inputs and environmental emissions (releases), evaluating/weighing the environmental impacts potentially associated with identified inputs (materials and energy) and outputs (emissions), and interpreting the results achieved in previous steps to make informed decisions.

A life cycle assessment (LCA) study typically consists of four distinguished steps as the following:

1) Goal and scope definition, 2) Inventory analysis, 3) Impact assessment, and 4) Interpretation as shown in Fig. 2.

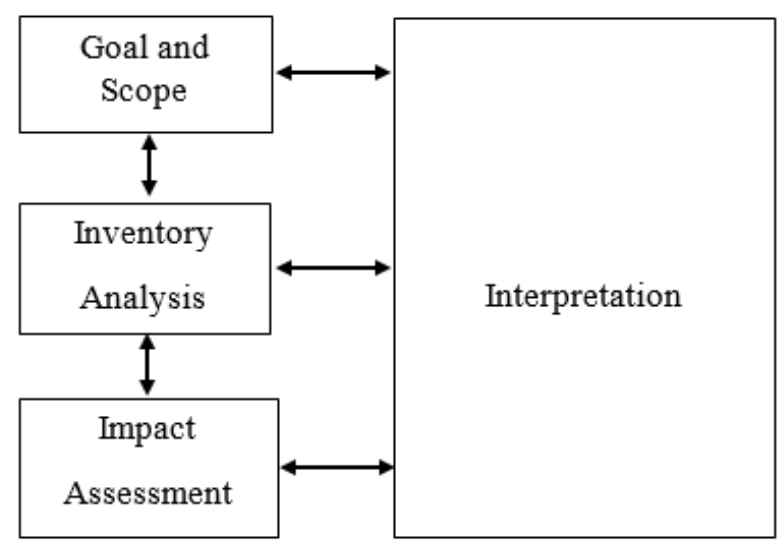

Fig.2. Framework of a life cycle assessment study

\subsubsection{Environmental Impact Assessment (EIA)}

One of the stages in a life cycle assessment is an environmental impact assessment (EIA). EIA is the method of measuring the anticipated impacts of a proposed process on the environment. In the case of EIA showing unacceptable effects, design features or further mitigation methods can be used to reduce or even avoid the impacts. 
The U.S. environmental protection agency, has introduced TRACl, the Tool for the Reduction and Assessment of Chemical and other environmental Impacts, to assist in life cycle assessment, industrial ecology, pollution prevention and process design.

To develop TRACl, the impact assessment methodology needed to be consistent with previous modeling especially of EPA. The human health non-cancer and cancer categories were mostly based on the assumptions made in EPA's Exposure Factors Handbook and Risk Assessment Guidance for Superfund.

TRACI has listed many characterization factors for different category of environmental impacts and different route of exposures (ecotoxicity, human health, global warming etc.) for more than 5000 chemicals. Environmental impact assessments can be done using characterization factors listed in TRACl. This can be done by a weighted as follows:

$I S=\sum_{i} \sum_{x} C F_{x, i} \cdot M_{x, i}$

where "IS" being the impact score (e.g. human health toxicity (cases); $\mathrm{CF}_{\mathrm{x}, \mathrm{i}}$ is the characterization of chemical $x$ which is released to compartment $i$ (cases $/ \mathrm{kg}$ ) and $\mathrm{M}_{\mathrm{x}, \mathrm{i}}$ is the emission of substance $\mathrm{x}$ to compartment $\mathrm{i}(\mathrm{kg})$. The two summations ensure that all the impacts associated with the release of different substances into different compartments were considered to calculate the total impact factor. The USEtox ${ }^{\mathrm{TM}}$ model ${ }^{26}$ calculates a wide variety of characterization factors for both carcinogenic and noncarcinogenic impacts of chemical emissions to different environmental compartments (urban air, rural air, freshwater, sea water ...). Table 1 tabulated the characterization factors related to the human health impacts of selected chemicals. The characterization factor units for the human toxicity is cases $/ \mathrm{kg}_{\text {emission. }}$. which is summarized as CTU (Comparative Toxic Unit) to emphasize on the comparative nature of CFs.

Table 1. Characterization factors associated with human health impacts (TRACl database)

\begin{tabular}{lcccc}
\hline & $\begin{array}{c}\text { Human health CF } \\
\text { [CTUnoncancer/kg], } \\
\text { Emission to urban } \\
\text { air, non-canc. }\end{array}$ & $\begin{array}{c}\text { Human health CF } \\
\text { [CTUnoncancer/kg], } \\
\text { Emission to cont. } \\
\text { freshwater, non- } \\
\text { canc. }\end{array}$ & $\begin{array}{c}\text { Human health CF } \\
\text { [CTUnoncancer/kg], } \\
\text { Emission to cont. } \\
\text { natural soil, non- } \\
\text { canc. }\end{array}$ & $\begin{array}{c}\text { CF Flag HH } \\
\text { non- } \\
\text { carcinogenic }\end{array}$ \\
\hline FORMALDEHYDE & $2.67 \mathrm{E}-07$ & $3.24 \mathrm{E}-07$ & $9.96 \mathrm{E}-08$ & Recommended \\
PHENOBARBITAL & $\mathrm{n} / \mathrm{a}$ & $\mathrm{n} / \mathrm{a}$ & $\mathrm{n} / \mathrm{a}$ & $\mathrm{n} / \mathrm{a}$ \\
CYCLOPHOSPHAMIDE & $\mathrm{n} / \mathrm{a}$ & $\mathrm{n} / \mathrm{a}$ & $\mathrm{n} / \mathrm{a}$ & $\mathrm{n} / \mathrm{a}$ \\
PREDNISOLONE & $\mathrm{n} / \mathrm{a}$ & $\mathrm{n} / \mathrm{a}$ & $\mathrm{n} / \mathrm{a}$ & $\mathrm{n} / \mathrm{a}$ \\
ESTRADIOL & $\mathrm{n} / \mathrm{a}$ & $\mathrm{n} / \mathrm{a}$ & $\mathrm{n} / \mathrm{a}$ & $\mathrm{n}$ \\
P,P'-DDT & $4.65 \mathrm{E}-05$ & $4.25 \mathrm{E}-04$ & $9.67 \mathrm{E}-07$ & $\mathrm{Recommended}$ \\
\hline
\end{tabular}

The effective dose for non-cancer human health $\left(\mathrm{ED}_{50}\right)$ predicted through the correlation developed in this study can be used to complete the necessary data for doing a comprehensive life cycle assessment (LCA) on different ionic liquids. 


\subsubsection{Characterization factor (CF) development}

Life cycle impact assessment ( $\mathrm{LCIA}$ ) methods use characterization factors to quantify the extent to which a chemical substance contributes to the environmental impacts. In this work the USEtox mode ${ }^{26}$, which is a state-of-the-art modeling framework based on scientific consensus for characterizing human and ecotoxicological impacts of chemicals, was utilized to develop characterization factors. In USEtox, the human health characterization factors of a substance of interest can be estimated through incorporating three parameters, as shown in Eqn. 1.

$\mathbf{C F}_{\text {Human Health }}=\mathbf{E F}_{\text {Human Health }} * \mathbf{F F} * \mathbf{X F}$

where EF relates to the inherent toxicity, FF relates to the fate factor and XF relates to potential routes and amount of exposure to the chemical of interest, respectively. In the following sections, the procedure for the development of each of these factors will be explained.

\section{Fate Factor}

Multimedia fate and transport models as shown in Fig. 3 are utilized to derive the environmental fate factors. These models represent the environment as several homogeneous compartments (e.g. air, water, and soil). The Intermedia transfer and distribution of a chemical compounds between different environmental compartments are modeled as a set of mass balance equations assuming equilibrium conditions. The fate factor, representing the persistence of a substance in an environmental compartment (residence time in days) depends on biodegradability, physicochemical properties and partitioning coefficients of the substance of interest. The current study estimates the fate factor of different ionic liquids through the approach proposed by USEtox model.

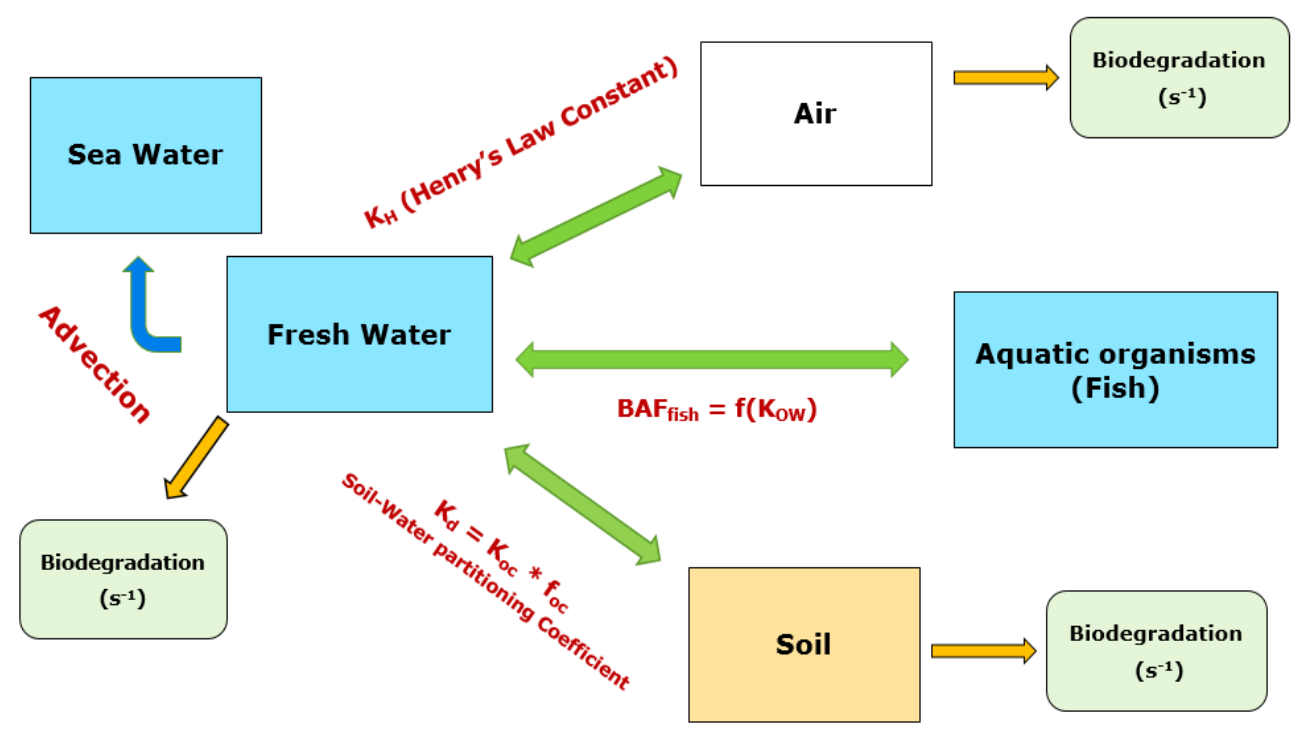

Fig.3. Multimedia Fate and transport model 


\section{Exposure Factor}

In USEtox, the exposure factors related to human health reflect the rate at which a pollutant can transfer from a receiving compartment into the human population through a series of exposure pathways. In USEtox $^{\mathrm{TM}}$, air (inhalation), drinking water (ingestion), unexposed produce (below-ground root crops), exposed produce (above-ground leaf crops, e.g. fruit and cereals), meat, dairy products and Fish are the pathways considered for the human exposure to chemical pollutants.

The exposure factor $\left(\right.$ days $\left.^{-1}\right)$ for drinking water or a specific food item at a certain scale equals.

$X F_{i, r}=B A F_{i, r} \cdot P R O D_{i} . P O P / M A S S_{r}$

where $\mathrm{BAF}_{\mathrm{i}, \mathrm{r}}$ being the bioaccumulation factor of the chemical of interest of exposure pathway $\mathrm{i}$ (e.g. fish) through compartment $r$ (e.g. seawater or freshwater) in $\mathrm{kg} / \mathrm{kg}, \mathrm{PROD}_{i}$ is the production of item $i$ in the exposure pathway per person (suggested value of $0.04-0.045 \mathrm{~kg} /$ day/person for fish living in freshwater), the variable POP represents the population number (e.g. 900 million on the continental scale), and MASS being the mass of compartment r (e.g. $6.8 \times 10^{14} \mathrm{~kg}$ of continental freshwater).

An illustrative example of the calculation of exposure factor (XF) for a specific ionic liquid, $\left[B \mathrm{Bmim}^{+}\left[\mathrm{PF}_{6}\right]^{-}\right.$.

The ionic liquid, $\mathrm{Bmim} \mathrm{PF}_{6}$ has a $\mathrm{BAF}$ of $5.73 \times 10^{-3} \mathrm{~kg} / \mathrm{kg}, \mathrm{PROD}_{i}$ is assumed to be equal to 0.04 $\mathrm{kg} / \mathrm{day} /$ person for freshwater fish, POP is 900 million on the continental and MASSr $=6.8 \times 10^{14} \mathrm{~kg}$ for continental freshwater.

$X F=\frac{5.73 \times 10^{-3} \times 0.04 \times 900 \times 10^{6}}{6.8 \times 10^{14} \mathrm{~kg}}=3.033 \times 10^{10}$

This approach was used to calculate the exposure factors for some common ionic liquidsas listed in Table 2.

Table 2. Exposure factors of some common ionic liquids

\begin{tabular}{ccc}
\hline $\mathrm{IL}$ & $\mathbf{B A F}_{\mathrm{i}, \mathrm{r}} \mathbf{( \mathbf { k g } / \mathbf { k g } ) ^ { 3 0 }}$ & $\mathbf{X F}_{\mathrm{i}, \mathrm{r}}$ \\
\hline$[\mathrm{Bmim}]^{+}[\mathrm{Br}]^{-}$ & $1.58 \times 10^{-4}$ & $8.15 \times 10^{-12}$ \\
{$[\mathrm{Bmim}]^{+}[\mathrm{Cl}]^{-}$} & $8.55 \times 10^{-4}$ & $4.53 \times 10^{-11}$ \\
{$[\mathrm{Bmim}]^{+}\left[\mathrm{BF}_{4}\right]^{-}$} & $8.94 \times 10^{-4}$ & $4.73 \times 10^{-11}$ \\
{$[\mathrm{Bmim}]^{+}\left[\mathrm{PF}_{6}\right]^{-}$} & $5.73 \times 10^{-3}$ & $3.03 \times 10^{-10}$ \\
{$[\mathrm{BPy}]^{+}[\mathrm{Cl}]^{-}$} & $6.04 \times 10^{-4}$ & $3.19 \times 10^{-11}$ \\
\hline
\end{tabular}

\section{Human Health Effect Factor}

In USEtox, the human health effect factors (EF) are used to show how change in life time intake of a pollutant (cases/kg intake) can change the life time disease probability. In USEtox ${ }^{\mathrm{TM}}$, distinct effect factors are derived for carcinogenic and non-carcinogenic effects. For each effect type, two different exposure routes of ingestion and inhalation are studied separately. The effect factors (EF) related to the human 
health are calculated if a linear concentration-response up to the point of $50 \%$ life time disease probability, as shown in Fig.4, is in effect.

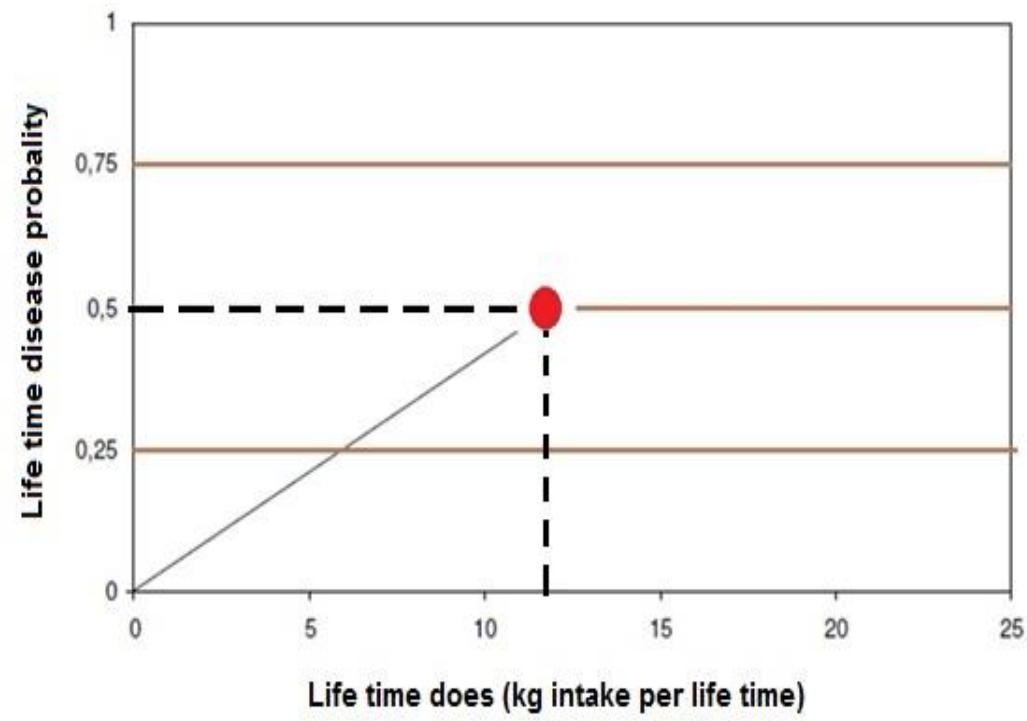

Fig.4. concentration-response up to the point of $50 \%$ life time disease probability

The human health toxicological effect factor of a chemical of interest can be estimated through the following equation:

$E F=\frac{0.5}{E D 50}$

For non-carcinogenic and carcinogenic effects, the $\mathrm{EDSO}_{\mathrm{h}, \mathrm{j}}$ for human health related to ingestion or inhalation exposure ( $\mathrm{kg} /$ person/lifetime) is calculated using the equation below.

$E D 50_{h, j}=\frac{E D 50_{a t, j} \cdot B W \cdot L T \cdot N}{A F_{a} \cdot A F_{t} \cdot 10^{6}}$

where $E D 50_{a, t, j}$ is the daily dose for the test animal (e.g. a rat or a mouse) during the time t (e.g. chronic or sub-chronic) per kg body weight (BW) of the species that causes a $50 \%$ chance of acquiring a disease through exposure route of $\mathrm{j}\left(\mathrm{mg} \cdot \mathrm{kg}^{-1} \cdot \mathrm{day}^{-1}\right) \cdot \mathrm{AF}_{\mathrm{a}}$ is the extrapolation factor used to convert the results related to one species to the other one (interspecies factors) which are listed in Table 3. $A F_{t}$ is the extrapolation factor to address the differences in time of exposure, (i.e. a factor of 2 is used to convert sub-chronic to chronic exposure $)^{27}, \mathrm{BW}$ is representing the average body weight of a human being (70-75 $\mathrm{kg}$ ), LT being the average lifetime of humans ( 70 years) and $\mathrm{N}$ is the number of days in one year used for unit conversion ( 365 days. year $\left.{ }^{-1}\right) .^{26}$ 
Table 3. A list of $A F_{a}$, interspecies factors

\begin{tabular}{lcc}
\hline Type & AF $_{\text {interspecies }}$ & $\begin{array}{c}\text { Average } \\
\text { Bodyweight } \mathbf{( k g )}\end{array}$ \\
\hline Human & 1.0 & 70 \\
Pig & 1.1 & 48 \\
Dog & 1.5 & 15 \\
Monkey & 1.9 & 5 \\
Cat & 1.9 & 5 \\
Rabbit & 2.4 & 2 \\
Hen & 2.6 & 1.6 \\
Mink & 2.9 & 1 \\
Guinea pig & 3.1 & 0.750 \\
Rat & 4.1 & 0.25 \\
Hamster & 4.9 & 0.125 \\
Gerbil & 5.5 & 0.075 \\
Mouse & 7.3 & 0.025 \\
\hline
\end{tabular}

In the next step, we chose 38 chemicals for which both the non-cancer human health toxicology data $\left(E D_{50}\right)$ from TRACl and in-vivo toxicity $\left(L_{50}\right)$ data for oral exposure of rats from the literature were available. We tried our best to select at least one chemical compound from each category (acids, aldehydes, aromatics, etc.). A linear correlation was developed to predict the non-cancer human health effective dose of chemicals from their in-vivo toxicicty data as shown in Fig.5.

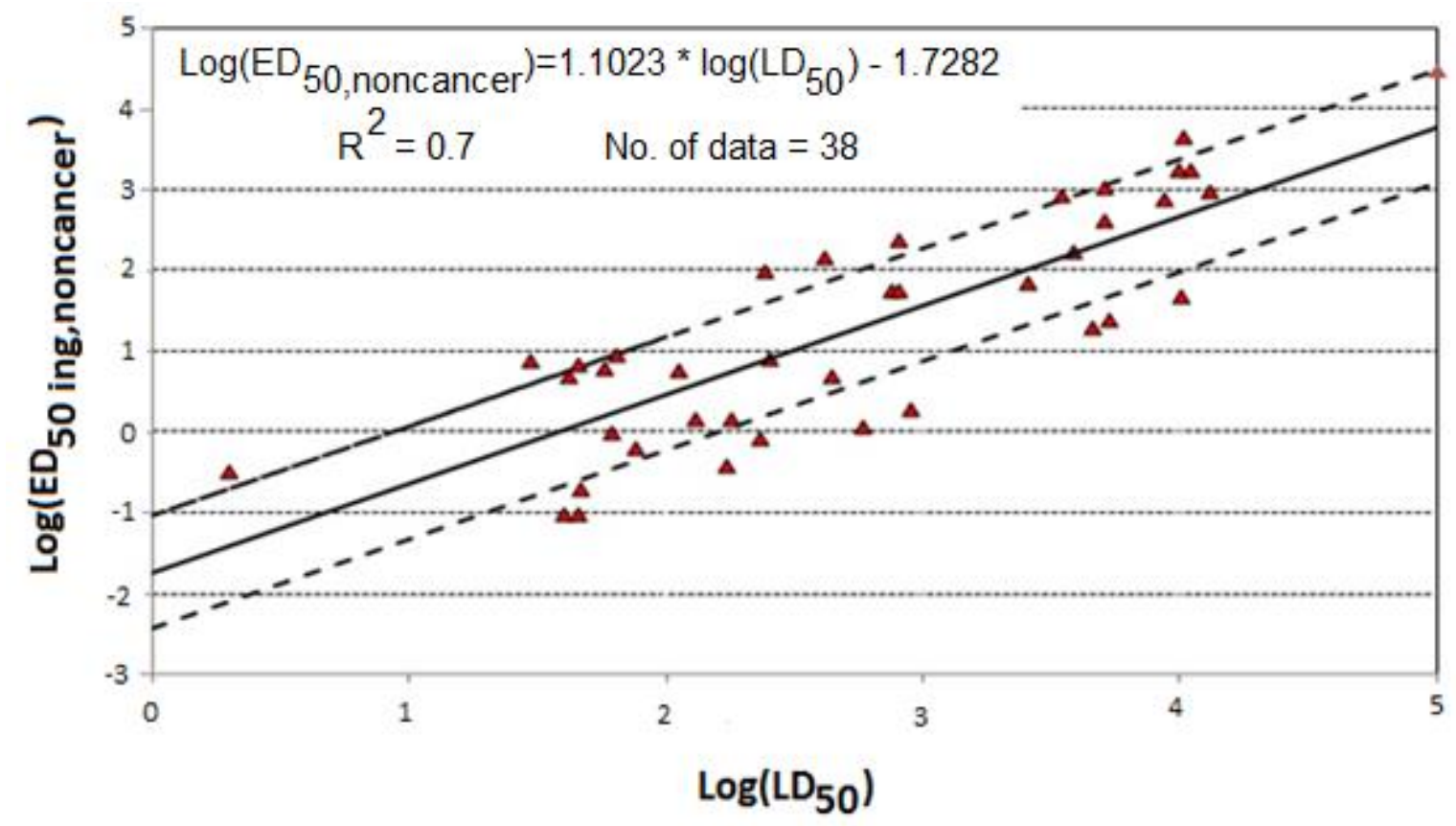

Fig.5 A linear correlation for $\mathrm{ED}_{50}$ Vs. $\mathrm{LD}_{50}$ data 
The algorithm shown in Fig. 6 can be used for any chemical of interest to give us an approximate value (as an start point) of $E D_{50, \text { non-cancer }}$ from the $\mathrm{IC}_{50}$ cytotoxicty data of that chemical towards human cell lines (e.g. HeLa cell).

\begin{tabular}{|c|c|c|}
\hline Step 1: & \multicolumn{2}{|l|}{ Cytotoxicity } \\
\hline \multicolumn{3}{|c|}{ Test 10-20 reference chemicals (low to high cytotoxicity) taken from the RC } \\
\hline Step 2: & Linear regression ana & \\
\hline \multicolumn{3}{|c|}{$\begin{array}{l}\text { Use IC50 toxicity values and } R C L D_{50} \text { values to calculate regression } \\
\qquad \log \left(L D_{50}\right)=a \times \log \left(I C_{50}\right)+b\end{array}$} \\
\hline Step 3: & Comparison of regress & \\
\hline \multicolumn{3}{|c|}{$\begin{array}{l}\text { Compare resulting regression with } \mathrm{RC} \text { regression } \\
\qquad \log \left(L D_{50}\right)=0.7003 \times \log \left(I C_{50}\right)+0.0897\end{array}$} \\
\hline \multicolumn{3}{|c|}{ Are they parallel? } \\
\hline \multicolumn{3}{|r|}{$\begin{array}{l}\text { Use recommended cells } \\
\text { and protocol to better } \\
\text { tune test sensitivity }\end{array}$} \\
\hline Step 4: & \multicolumn{2}{|c|}{ Use of the secondary regression } \\
\hline \multicolumn{3}{|c|}{$\log \left(E D_{50, \text { noncancer }}\right)=1.1023 \times \log \left(L D_{50}\right)-1.7282$} \\
\hline Step 5: & $\begin{array}{l}\text { Use the predicted ED } 50 \text { data to pe } \\
\text { On the human health impac }\end{array}$ & $\begin{array}{l}\text { rm a life cycle assessment } \\
\text { f the selected ILs }\end{array}$ \\
\hline
\end{tabular}

Fig.6 Algorithm to predict the ED50 for a chemical of interest

The predicted value of in-vivo toxicity $\left(\mathrm{LD}_{50}\right)$ along with the non-cancer human health toxicity $\left(\mathrm{ED}_{50}\right)$ data for a few ionic liquids are listed in Table 4. 
Table 4. Predicted values of in-vivo toxicity $\left(\mathrm{LD}_{50}\right)$ and non-cancer human toxicity $\left(\mathrm{ED}_{50}\right)$ for ILS

\begin{tabular}{|c|c|c|c|c|}
\hline IL & $\mathrm{MW}$ (g/mol) & $\log \left(I C_{50}\right)[\mu M]^{14}$ & $\begin{array}{l}\log \left(\operatorname{LD}_{50}\right) \\
{[\mathrm{mmol} / \mathrm{kg}]}\end{array}$ & $\begin{array}{l}\mathrm{ED}_{50 \text {,ing non-cancer }} \\
\text { [kg/lifetime] }\end{array}$ \\
\hline$[\mathrm{Bmim}]^{+}[\mathrm{Br}]^{-}$ & 219.122 & 3.44 & 2.498 & 10.6 \\
\hline$[\mathrm{Bmim}]^{+}[\mathrm{Cl}]^{-}$ & 174.67 & & ------ & ------------ \\
\hline$[\mathrm{Bmim}]^{+}\left[\mathrm{BF}_{4}\right]^{-}$ & 226.03 & 3.72 & 2.694 & 17.43 \\
\hline$[\mathrm{Bmim}]^{+}\left[\mathrm{PF}_{6}\right]^{-}$ & 284.18 & 4.14 & 2.988 & 36.76 \\
\hline$[\mathrm{BPy}]^{+}[\mathrm{Cl}]^{-}$ & 171.667 & ----- & ------ & -------- \\
\hline
\end{tabular}

Stepnowski et al ${ }^{28}$ reported a value of $13.9 \mathrm{mmol}^{-1} \mathrm{~L}^{-1}$ for $\mathrm{IC}_{50}$ of $[\mathrm{Bmim}]^{+}\left[\mathrm{PF}_{6}\right]^{-}$using of this value in the correlative model developed in this study resulted in an $\mathrm{LD}_{50}$ of $276.43 \mathrm{mg} / \mathrm{kg}$, which is in close vicinity of the experimental value of $300 \mathrm{mg} / \mathrm{kg}$ for the $L_{50}$ of the selected ionic liquid for oral intake by rats. ${ }^{29}$

In our previous study, the fate factors of common ionicliquids were calculated. ${ }^{30}$ These fate factors, along with the effect and exposure factors calculated in this study, were used to develop new characterization factors for non-cancer human health impacts of common ionic liquids as tabulated in Table 5.

Table 5. Characterization factors of non-cancer human health of conventional ionic liquids

\begin{tabular}{|c|c|c|c|c|}
\hline IL & $\mathrm{EF}\left[\right.$ cases $\left./ \mathrm{kg}_{\text {intake }}\right]$ & FF [days][ref] & $X F\left(\right.$ days $\left.^{-1}\right)$ & $\begin{array}{c}\text { CF (CTUnon- } \\
\text { cancer/kg) }\end{array}$ \\
\hline$[\mathrm{Bmim}]^{+}[\mathrm{Br}]^{-}$ & 0.0471 & 131.5 & $8.15 \times 10^{-12}$ & $5.04 \times 10^{-11}$ \\
\hline$[\mathrm{Bmim}]^{+}[\mathrm{Cl}]^{-}$ & --------- & 010.1 & $4.53 \times 10^{-11}$ & -------- \\
\hline$[\mathrm{Bmim}]^{+}[\mathrm{BF} 4]^{-}$ & 0.0287 & 122.4 & $4.73 \times 10^{-11}$ & $1.66 \times 10^{-10}$ \\
\hline$[\mathrm{Bmim}]^{+}[\mathrm{PF} 6]^{-}$ & 0.0136 & 142.9 & $3.03 \times 10^{-10}$ & $5.88 \times 10^{-10}$ \\
\hline$[\mathrm{BPy}]^{+}[\mathrm{Cl}]^{-}$ & ----------- & 143.3 & $3.19 \times 10^{-11}$ & --------- \\
\hline
\end{tabular}

\section{Acknowledgement}

This material is based upon work supported by the United States National Science Foundation (CAREER Program) under Grant No. 1151182. 


\section{References}

1. Wasserscheid, P., Welton, T. (eds). Ionic Liquids in Synthesis. Wiley-VCH(2007).

2. Arce, A., Earle, M.J., Rodriguez, H. \& Seddon, K.R. Separation of aromatic hydrocarbons from alkanes using the ionic liquid 1-ethyl-3-methylimidazolium bis(trifluromethylsulfonyl) amide. Green. Chem. 9, 70-74 (2007).

3. Karunanithi, A.T., \& Mehrkesh, A. Computer-aided design of tailor-made ionic liquids. AlChE Journal59, 4627-40 (2013).

4. Fernicola, A., Croce, F., Scrosati, B., Watanabe, T. \& Ohno, H. LiTFSI-BEPyTFSI as an improved ionic liquid electrolyte for rechargeable lithium batteries. J. Power Sources 174, 342-48 (2007).

5. Brennecke, J.B. \& Gurkan, B.E. Ionic Liquids for $\mathrm{CO}_{2}$ Capture and Emission Reduction. J. Phys. Chem. Lett. 1, 3459-64 (2010).

6. Swatloski, R.P., Spear, S.K., Holbrey, J.D., \& Rogers, R.D. Dissolution of cellulose with ionic liquids. J. Am. Chem. Soc. 124, 4974-75 (2002).

7. Moens, L., Blake, D.M., Rudnicki, D.L., \& Hale, M.J. Advanced thermal storage fluids for solar parabolictrough systems. Transaction of the American Society of Mechanical Engineers 125, 11216 (2003).

8. Mehrkesh, A. \& Karunanithi, A.T. Optimal Design of Ionic Liquids for Thermal Energy Storage. Computers \& Chemical Engineering 93, 402-12 (2016).

9. Lu, W., Fadeev, A.G., Qi, B., Smela, E., Mattes, B.R., Ding, J., Spinks, G.M., Mazurkiewicz, J., Zhou, D., Wallace, G.G., MacFarlane, D.R., Forsyth, S.A., \& Forsyth, M. Use of ionic liquids for piconjugated polymer electrochemical devices. Science 297, 983-87 (2002).

10. Dubois, P., Marchand, G., Fouillet, Y., Berthier, J., Douki, T., Hassine, F., Gmouh, S., \& Vaultier, M. Ionic Liquid Droplet as e-Microreactor. Anal. Chem. 78, 4909-17 (2006).

11. Plechkova, N.V., \& Seddon, K.R. Chem. Soc. Rev. 37, 123 (2008).

12. Jain, N., Kumar, A., Chauhan, S., \& Chauhan, S.M.S. Chemical and biochemical transformations in ionicliquids. Tetrahedron 61, 1015-60 (2005). 
13. Bubalo, M.C., Radošević, K., Redovniković, I. R., Halambek, J., \& Srček, V.G. A brief overview of the potential environmental hazards of ionic liquids. Ecotoxicology and environmental safety 99, 1-12 (2014).

14. Pham, T.P.T., Cho, C.W., \& Yun, Y.S. Environmental fate and toxicity of ionic liquids: a review. Water research 44, 352-72 (2010).

15. Chen, H.L., Kao, H.F., Wang, J.Y., \& Wei, G.T. Cytotoxicity of Imi dazole lonic Liquids in Human Lung Carcinoma A549 Cell Line. Journal of the Chinese Chemical Society 61, 763-69 (2014).

16. Ganske, F., \& Bornscheuer, U.T. Growth of Escherichia coli, Pichia pastoris and Bacillus cereus in

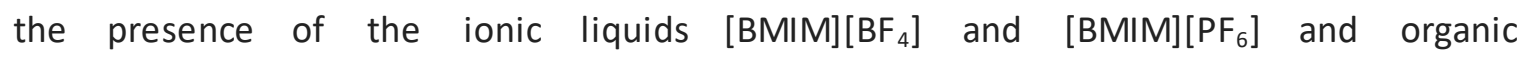
solvents. Biotechnology letters 28, 465-69 (2006).

17. Cornmell, R.J., Winder, C.L., Tiddy, G.J., Goodacre, R., \& Stephens, G. Accumulation of ionic liquids in Escherichia coli cells. Green Chemistry 10, 836-41 (2008).

18. Jodynis-Liebert, J., Nowicki, M., Murias, M., Adamska, T., Ewertowska, M., Kujawska, M., ... \& Pernak, J. Cytotoxicity, acute and subchronic toxicity of ionic liquid, didecyldimethylammonium saccharinate, in rats. Regulatory Toxicology and Pharmacology 57, 266-73 (2010).

19. Pretti, C., Chiappe, C., Baldetti, I., Brunini, S., Monni, G., \& Intorre, L. Acute toxicity of ionic liquids for three freshwater organisms: Pseudokirchneriella subcapitata, Daphnia magna and Danio rerio. Ecotoxicology and environmental safety 72, 1170-76 (2009).

20. Mehrkesh, A., \& Karunanithi, A.T. Energeticionic materials: How green are they? A comparative life cycle assessment study. ACS Sustainable Chemistry \& Engineering 1, 448-55 (2013).

21. Mehrkesh, A., \& Karunanithi, A.T. New perspective on computer aided molecular design: a life cycle assessment approach. In Proceedings of the 8th International Conference on Foundations of Computer-Aided Process Design (Vol. 34, p. 369). Elsevier. (2014, July)

22. García-Lorenzo, A., Tojo, E., Tojo, J., Teijeira, M., Rodríguez-Berrocal, F. J., González, M. P., \& Martínez-Zorzano, V. S. (2008). Cytotoxicity of selected imidazolium-derived ionic liquids in the human Caco-2 cell line. Sub-structural toxicological interpretation through a QSAR study. Green chemistry 10, 508-16 (2008).

23. Frade, R.F., Matias, A., Branco, L.C., Afonso, C.A., \& Duarte, C.M. Effect of ionic liquids on human colon carcinoma HT-29 and CaCo-2 cell lines. Green Chemistry 9, 873-77 (2007). 
24. National Institute of Environmental HealthSciences. Guidance document on using in vitro data to estimate in vivo starting doses for acute toxicity. North Carolina: NIH Publication. (2001)

25. Rahbari, R., Sheahan, T., Modes, V., Collier, P., Macfarlane, C., \& Badge, R.M. A novel L1 retrotransposon marker for HeLa cell line identification. Biotechniques 46, 277 (2009).

26. Rosenbaum, R.K., Bachmann, T.M., Gold, L.S., Huijbregts, M.A., Jolliet, O., Juraske, R., ... \& McKone, T.E. USEtox-the UNEP-SETAC toxicity model: recommended characterization factors for human toxicity and freshwater ecotoxicity in life cycle impact assessment. The International Journal of Life Cycle Assessment 13, 532-46 (2008).

27. Huijbregts, M.A., Rombouts, L.J., Ragas, A.M., \& van de Meent, D. Human-toxicological effect and damage factors of carcinogenic and noncarcinogenic chemicals for life cycle impact assessment. Integrated Environmental Assessment and Management 1, 181-244 (2005).

28. Stepnowski, P., Skladanowski, A.C., Ludwiczak, A., \& Laczyńska, E. Evaluating the cytotoxicity of ionic liquids using human cell line HeLa. Human \& experimental toxicology 23, 513-17 (2004).

29. National Toxicology Program (NTP), National Institute of Environmental Health Sciences (NIEHS) U.S Department of Health and Human Services Scott A. Masten, Ph.D. Research Triangle Park, North Carolina, May (2004).

30. Mehrkesh, A. \& Karunanithi, A.T. Life-Cycle Perspectives on Aquatic Ecotoxicity of Common Ionic Liquids. Environmentalscience \& technology 50, 6814-21 (2016). 